\title{
Introduction: International Health Organisations and their Histories
}

\author{
Iris Borowy, James H. Mills and Yong-an Zhang
}

The papers in this collection date from conferences held at Shanghai University from 2013 onwards under the auspices of the International Health Organizations (IHOs): The History for the Future Network set up in that year. ${ }^{1}$ Designed to bring together scholars all over the world engaged in various aspects of writing the history of IHOs, the lively debates at subsequent events show that, while the field can look back to a formidable publication record already, these organizations are clearly of greater interest than ever before as a topic for current and future historical research.

Part of the fascination of IHOs results from the fact that they have a dual nature, being at once immersed in the politics of international governance and in the processes by which health has been defined and debated. As a result, they sit at a point where they connect two different fields and historiographies, those of international relations and of medicine. On the one hand IHOs can be perceived as part of a larger story of the evolution of international organizations in general, which came to occupy an increasingly important place in the twentieth century. On the other, they can be seen as one of many actors in the development of modern health systems as these have been wrought in the changing concepts, technologies and biological challenges of the modern period. Approaching IHOs from one perspective or the other means that relevant questions differ dramatically. With regard to international relations, relevant factors include the prevailing political climate, the interests of individual governments and their departments, and the alliances, tensions and conflicts between particular nations. For scholars exploring international organizations in general crucial questions address institutional set-up, leadership, structure, decision-making processes, funding mechanisms, working procedures and

1 The organizers would like to thank the UK's Arts and Humanities Research Council for resourcing the early stages of this network, the Wellcome Trust for funding its inaugural conference in 2013, and the Universities of Shanghai and Strathclyde for their support. The network's first organizing committee in 2013 consisted of Sanjoy Bhattacharya (York University), Iris Borowy (Shanghai University), Walter Bruchhausen (Aachen University), Nitsan Chorev (Brown University), Martin Gorsky (London School of Hygiene and Tropical Medicine) and James Mills (University of Strathclyde). 
hiring strategies. For scholars studying developments in health, relevant questions address issues of bio-medical knowledge, of interpretations of health as primarily grounded in biology or social circumstances, of etiological theories and of therapeutic and preventive practices and the politics behind them. Scholars confronted with IHOs need therefore to draw on several sets of questions and approaches, and, depending on the focus of the particular study, some will loom larger than others.

A further challenge is to establish what exactly should count as an IHO: is it a public organization with governments as members? Does it have to be affiliated with the League or United Nations system of global governance which emerged in the twentieth century? Or can it be just any institution in which groups engaged in health work in different countries collaborate? There is a risk that, in drawing the definition too narrowly, the focus is limited to the largest or most enduring organisations and therefore analyses are offered of only the most successful or adept institutions. By contrast, applying too broad a definitions risks creating a field that becomes unwieldy for those seeking to survey it while the very idea of an IHO becomes unstable or unusable in the face of multiple forms and case studies. Implicitly or explicitly, any scholar studying IHOs faces the two questions raised above: what exactly constitutes an IHO and what is the primary characteristic by which it could or should be approached?

Histories of IHOs have approached these questions in various ways. The earliest narratives of IHO history were set by participants, staff members who took to writing the history of what they saw as their sector of work after years of service in one or several of the IHOs. For years the only available monograph on the topic was International Health Organizations And Their Work, published in 1952 by Neville Goodman. ${ }^{2}$ His history of IHOs begins with the Sanitary Conferences during the nineteenth century and continues forward to the organizations, established by agreements between governments, in the twentieth century. His answers to the questions above were shaped by his focus on those IHOs in which he was personally involved, the Office International d'Hygiene Publique, the League of Nations Health Organisation and the World Health Organization. In his account, and reflecting his experience, administrative structure was as important as the health issues at hand, and he set the template for subsequent research by discussing both, while largely ignoring the impact of scientific, non-governmental or commercial groups external to the IHOs. This basic premise of IHOs as intergovernmental agencies was confirmed twenty years later by long-time WHO staff member Norman HowardJones. In a narrative that would soon become outdated, his account privileges a view of great men making history. While this focus on personalities in various positions within and outside of IHOs does offer some colour to what might otherwise be dry institutional history, his reliance on key official documents privileges the

2 Neville M. Goodman, International Health Organizations and Their Work, (Edinburgh / London: Churchill Livingstone, 1952, 2nd extended edition 1971). 
administrative side of IHOs, notably those processes by which they were created, modified or ended. As a result, the long years in between i.e. the time in which IHOs did the work that would define them, receive comparatively scant attention. ${ }^{3}$ Some decades later, other colleagues took a wider view. Writing in 1993, Milton Roemer interpreted "internationalism in medicine and public health" as encompassing a broader range of possible actors while being more connected to the underlying medical questions. As a long-time partisan of social approaches to health policies, this perspective inevitably shaped his writings. ${ }^{4}$ Socrates Litsios, still writing today, broadened the field by freely mixing publications on his former employer, the $\mathrm{WHO}$, with studies of private groups active in international health during the twentieth century, including the Rockefeller Foundation and the Christian Medical Commission.

The studies of historians without a background in IHO careers have continued to add depth to the narrative by addressing more topics and agencies. Scholars still see the beginning of systematic international health cooperation in the arrival of cholera in mid-nineteenth century Europe and the Sanitary Conferences which were organized in response. ${ }^{6}$ But they complement this picture by acknowledging that from early on issues other than infectious diseases also played a role, including such diverse topics as the perceived need to coordinate policies regarding narcotic drugs,

3 Norman Howard-Jones, International Public Health between the Two World Wars - The Organizational Problems, (WHO, Genf 1978); Norman Howard-Jones, The Pan-American Health Organization: Origins and Evolution, (WHO, Geneva 1981).

4 Milton I. Roemer, "Internationalism in Medicine and Public Health." in W. F. Bynum and Roy Porter, eds., Companion Encyclopedia of the History of Medicine (London / New York, 1993), pp. 1928-1939.

5 Socrates Litsios, The third ten years of the World Health Organization (Geneva, 2009); Socrates Litsios, The fourth ten years of the World Health Organization (Geneva, 2012); Socrates Litsios, "Selskar Gunn and China: The Rockefeller Foundation's 'Other' Approach to Public Health", Bulletin of the History of Medicine, 79: 2 (2005), 295-318; Socrates Litsios, "Fred L. Soper's Ignored Criticism of WHO's Approach to Malaria Eradication", Parasitologia, 42 (2000), 167-172; Socrates Litsios, "The Long and Difficult Road to Alma-Ata: A Personal Reflection", International Journal of Health Services, 32: 4 (2002), 709-732; Socrates Litsios, "WHO, PHC and the NGO Community : the Need for a More Focused Commitment", Development journal on Politics of Health, 47: 2 (2004), 57-63; Socrates Litsios, "The Christian Medical Commission and the Development of WHO's Primary Health Care Approach”, American Journal of Public Health, 94: 11 (2004), 1884-1893; Socrates Litsios, "Selskar Gunn and China: The Rockefeller Foundation's 'Other' Approach to Public Health”, Bulletin of the History of Medicine, 79 (2005), 295-318; Socrates Litsios, "The Rockefeller Foundation's Struggle to Correlate Its Existing Medical Program with Public Health Work in China" in Iris Borowy, ed., Uneasy Encounters: The Politics of Medicine and Health in China 1900-1937, (Berlin, 2009), pp. 177-203.

6 Mark Harrison, "Disease, diplomacy and international commerce: the origins of international sanitary regulation in the nineteenth century", Journal of Global History, 1: 2 (2006), 197-217. 
alcohol, occupational safety and transboundary pollution. ${ }^{7}$ Nevertheless, many recent studies have still focused on IHOs in a narrow sense, e.g. IHO whose main function was to work on international health work and which carried "health" in its name, mainly the World Health Organization (WHO), ${ }^{8}$ the League of Nations Health Organisation, or the Pan-American Health Organization..$^{10}$ But as time and IHO activities progress, historical studies increasingly focus on individual programs, campaigns or regions, which invariably contextualizes IHO as actors within a larger web of global, regional and local actors (including other IHOs) working towards a specific health-related goals. To name just a few examples, this is true with regard to eradication campaigns, notably smallpox ${ }^{11}$ and malaria, ${ }^{12}$ child care, ${ }^{13}$ social approaches to health policies, ${ }^{14}$ or the relations of IHO work to specific regions such as Asia, ${ }^{15}$ or Latin America. ${ }^{16}$

In a diversion from this pattern a comparatively large amount of research has consistently focused on the Rockefeller Foundation, whose International Health Board/Division engaged in international health from the early twentieth-century. It formed part of a private institution and cooperated with, but never belonged to, the public IHOs listed above. ${ }^{17}$ The integration of the Rockefeller Foundation into the standard canon of IHO literature opened up the question of what defines an IHO beyond those of intergovernmental organizations dedicated to health (and nothing else). The Rockefeller Foundation was not based on governmental membership, it

7 David Fidler, "The globalization of public health : the first 100 years of international health diplomacy", Bulletin of the World Health Organization, 79: 9 (2001), 842-49.

8 Kelley Lee, The World Health Organization (London/New York, 2009).

9 Iris Borowy, Coming to Terms with World Health (Berlin, 2009).

10 Norman Howard-Jones, The Pan-American Health Organization: Origins and Evolution, (Geneva, 1981); Marcos Cueto, The Value of Health. A History of the Pan American Health Organization (Washington, 2007).

11 Sanjoy Bhattacharya, The Global Eradication of Smallpox (Hyderabad, 2011).

12 Darwin Stapleton, "Internationalism and nationalism: the Rockefeller Foundation, public health, and malaria in Italy, 1923-1951", Parassitologia, 42: 1-2 (2000), 127-34; Kamini Mendis, et al. "From Malaria Control to Eradication: The WHO Perspective", Tropical Medicine \& International Health, 14: 7 (2009), 802-809.

13 James Gillespie, "International organizations and the problem of child health, 19451960", Dynamis, 23 (2008), 115-142.

14 Esteban Rodríguez-Ocana, ed., The Politics of the Healthy Life (Sheffield, 2003); Iris Borowy, "International Social Medicine Between the Wars. Positioning a Volatile Concept," Hygiea Internationalis, 6: 2 (2007), 13-35.

15 Sunil Amrith, Decolonizing International Health. India and Southeast Asia, 1930-65 (Houndmills, 2006).

16 Paul Weindling, "As origens da participação da América Latina na Organização de Saúde da Liga das Nações, 1920 a 1940," Historia ciencia saúde-Manguinhos, 13: 3 (2006), 555-570.

17 Marcos Cueto, ed., Missionaries of Science. The Rockefeller Foundation and Latin America (Bloomington, 1994); John Farley, To Cast Out Disease. A History of the International Health Division of the Rockefeller Foundation (1913-1951) (Oxford, 2004); Stephen Palmer, Launching Global Health. The Caribbean Odyssey of the Rockefeller Foundation (Ann Arbor, 2010). 
was not financed by public money nor was its work decided by some body whose members cooperated under some sort of representative voting system. It was not even international in the sense that its leading officials had different nationalities. But its work was directed at health in countries around the world, its financial power provided it with a lot of room for manoeuver, and its close cooperation with other IHOs, notably the League of Nations Health Organisation, firmly integrated it into the system in which multiple IHOs collectively formed a field perceived as international health. Studies of their working methods revealed that a lot of the activities in international health involved inter-agency collaboration as experts in the field often regarded each other as colleagues in a shared endeavor rather than as members of distinct institutions. Using health-related activities as a defining characteristic rather than organizational character certainly increased the number of actors and broadened perspectives for historians.

Paul Weindling took this approach that focused on health work rather than on institutional framework when he dedicated his 1995 collected volume to International Health Organisations and Movements 1918-1939. Among others, it included contributions on the League of Red Cross Societies and the Pasteur Institutes, effectively adding social work and laboratory science to this field of research. ${ }^{18}$ Conversely, analyses based on organizations could come with a new interpretation of health. When Amy Staples combined studies of the Food and Agriculture Organization, of the World Bank, and of the WHO she portrayed them as partners in a common endeavor towards world development. In doing so she implicitly defined health as a component of a larger socio-economic framework, rather than as an isolated aim in itself. ${ }^{19}$ This drew attention to other organizations whose work on general developmental issues led them to become involved in health matters. This has been particularly true for the World Bank, an organization without an original mandate in health, but which became one of the major players in international health in recent decades, affecting and sometimes eclipsing the work of traditional IHOs for whom health is the core responsibility. ${ }^{20}$ Other institutions such as UNDP or UNICEF have also contributed substantial funds and efforts in international health work. $^{21}$ Adding new actors, such as the People's Health Movement or the Global

18 Paul Weindling, ed., International Health Organisations and Movements 1918-1939 (Cambridge, 1995), pp. 134-153.

19 Amy Staples, The Birth of Development (Kent, 2006).

20 Ane Ubalde and J.T. Jackson, "The World Bank and International Health Policy: A critical review", Journal of International Development, 7: 3 (1995), 525-541; Jennifer Ruger, "The Changing Role of the World Bank in Global Health", American Journal of Public Health, 95: 1 (2005), 60-70; Theodore Brown, Marcos Cueto and Elizabeth Fee, "The World Health Organization and the Transition from 'International' to 'Global' Public Health", American Journal of Public Health, 96: 1 (2006), 62-72; Devi Sridhar, The Battle Against Hunger: Choice, Circumstance and the World Bank (Oxford, 2008).

21 For an interesting, though somewhat dated overview see Meri Koivusalo and Eeva Ollila, Makina a Healthy World (London, 1997). 
Fund, and those writing the history of international health organizations find themselves in an increasingly crowded field. ${ }^{22}$ This is likely to remain the case as "new" IHOs keep being discovered. An upcoming volume by Peter Carroll and Adrian Kay, which explores the role of the OECD and that of its predecessor, the OEEC, in the global health interactions and policies, forms the latest example of this trend. $^{23}$

As the number of potential IHOs available for study by historians is growing while categories and perspectives multiply, writing the histories of IHOs has never been a more diverse practice. This collection of papers is meant to be a contribution to this evolving field and, by encapsulating a diversity of actors, topics and approaches, to make the job of any future definitive work, should it be attempted, even more difficult. The spectrum of material covered in these seven papers is deliberately broad. The list of IHOs includes WHO, UNICEF, ILO, the World Council of Churches Christian Medical Commission, the League of Red Cross Societies (LRCS), the International Office of Public Health (OIHP), the International Union against Venereal Diseases (UICPV), the Union against Venereal Diseases and Treponematoses (IUAVDT) and the Commission for Technical Cooperation in Africa South of the Sahara. The health issues discussed range from tuberculosis to sexually-transmitted diseases, from environmental health to cannabis consumption, and from development aid to Health for All programmes. In the process, the papers address debates on topics as diverse as preventive measures, health infrastructures for itinerant workers, the problems of defining emerging health issues, the goals of health aid policies, the organization of regional responsibility for IHOs as well as theories about how IHOs fit into the larger picture of international organizations. The geographical range stretches from the European Rhineland to South Asia, from French Colonies to post-War Occupied Territories, and from the offices of New York to the churches of West Germany. The period ranges from the 1920s to today. If nothing else, these papers demonstrate that research on IHOs draws on a large spectrum of research questions, case studies, places, people and eras.

Nevertheless, it is evident that common themes lurk behind this diversity. Not surprisingly, money and its impact is a recurring theme. Nils Brimnes argues that, eventually, superior funds carried the day for UNICEF in its struggle with WHO and allowed it to establish its anti-tuberculosis as the international norm. Sławomir Łotysz demonstrates how the difficulty of coordinating health insurance across numerous borders and different health care systems complicated efforts to provide

22 Ravi Narayan and Claudio Schuftan, "People's Health Movement," in Guy Carrin et al., eds. Health Systems Policy, Finance and Organization (Oxford and San Diego, 2009), 124-127; Isabel Yan, Eline Korenromp and Eran Bendavid, "Mortality changes after grants from the Global Fund to Fight AIDS, tuberculosis and malaria: an econometric analysis from 1995 to 2010", BMC Public Health, 15: 977 (2015), DOI: 10.1186/s12889-015-2305-1.

23 Peter Carroll and Adrian Key, Global Health Governance and the OECD (World Scientific Publications, 2016). 
anti-VD services to sailors working on the Rhine. Jessica Pearson-Patel points out that part of international opposition to a WHO office in Africa resulted from anxieties about future costs. Jim Mills suggests that when the WHO dismissed cannabis as a source of medicines in the 1950s the protests of the Indian government were driven by pharmaceutical interests at home. Finally, Iris Borowy argues that the global chemical industry created its own IHO to produce evidence to support claims about the safety of its products from fear of the economic implications of finding health hazards in synthetic compounds. Her discussion of the industry-funded European Centre for Ecotoxicology and Toxicology of Chemicals is important as it draws attention to corporations as a type of IHO often neglected by historians looking at such organizations. They commercial businesses differ from non-profit oriented IHOs in important ways, it is nevertheless important to acknowledge that the many companies selling anything from top of the range hospital equipment or pharmaceuticals to everyday items like soap, sanitary towels and plasters often have global reach. Their agendas and actions are as mixed as those of any other IHOs and their impacts likely to be just as significant in transmitting ideas, changing practices and shaping lives.

Secondly, several papers recount the various struggles of IHOs in determining scientific knowledge and transforming it into authoritative information, clearly one of their core responsibilities. Brimnes and Mills demonstrate that these struggles were neither agenda- not interest-free and that the selection and interpretation of information formed part of the strategies of different IHOs to establish their position within the scene of international organizations. Conversely, Borowy focuses on the real difficulty of making sense of an emerging health threat whose nature seemed to contradict established scientific regimes.

Another theme that emerges from a number of these papers is the importance of IHOs as actors. Contradicting a view of international organizations as mere vehicles for the policies of member countries a number of organizations emerge from this collection with some form of corporate identity and agency of their own. Nitsan Chorev makes this thesis the centre of her analysis of IHOs as objects for theorists of international organizations. The idea is also implicitly adopted by Niels Brimnes in his analysis of the competition between WHO and UNICEF for practical and conceptual supremacy in global anti-tuberculosis policies and by Jim Mills in his analysis of the ways in which both WHO and UN commissions used a selective reading of available data regarding Cannabis consumption to serve their own agendas by condemning the substance. The idea is also inherent in Jessica Pearson-Patel's paper on French efforts to prevent or contain the establishment of a regional WHO office in Africa. The French aversion to such an office was based on the assumption that it would pursue a political line that would not necessarily fit in with the interests of French colonies there. The papers by Iris Borowy and Walter Bruchhausen bolster the view that IHOs came with their own specific religious, scientific or economic characters which influenced their perspectives on issues of international health. In all 
cases, IHOs pursued agendas of their own derived from their own well-established, if evolving, institutional identities.

However, this does not mean that IHOs were either homogeneous or that they acted in vacuums. Repeatedly the papers demonstrate that national actors could and did try to influence the policies of IHOs, successfully in the cases of the Indian and British governments regarding Cannabis (Mills) and of German non-governmental development aid agencies with regard to health development policies (Bruchhausen), but unsuccessfully in the case of others, such as the French government and its approach to WHO representation in Africa (Pearson-Patel). Even more strongly, the papers portray a scene of international health in which inter-agency cooperation was the norm rather than the exception. The multiplicity of health and social organizations active along the river Rhine, the WHO and UNICEF tuberculosis commissions, bodies involved with chemical safety in various international organizations or $\mathrm{WHO}$ and UN in general, have all been compelled to cooperate in this complex field of international health, where diseases and health conditions do not recognize national borders and where determinants of health cut across disciplines. Even the Commission for Technical Cooperation in Africa South of the Sahara, whose main purpose was to counteract a regional WHO body, was characterized by large overlap of members with the office it was supposed to oppose.

Finally, the papers in this collection are united in their top-down approach which grants only fleeting appearances to those at whom the policies in question were addressed: the Asian cannabis consumers, the boatmen of the Rhine, the congregations of the Christian missions and those of us unknowingly consuming substances thought to be endocrine disruptors. This omission, owed largely to the difficulty of finding suitable sources, is a common characteristic of this literature, shared by other historians in the field. Nevertheless, the people concerned are omnipresent, albeit indirectly, as subjects of IHO surveys, debates, regulations, therapeutic or preventive provisions or other policies, and repeated references over time hint at their agency in a web of mutually reinforcing or contradicting determinants. When cannabis consumers in India (and elsewhere) have continued their habit, when boatmen on the Rhine have chosen the location for medical consultation, when church members in Africa and Germany have communicated their expectations to missionary organizations, when patients around the world have chosen (not) to cooperate with measures in anti-TB campaigns and when consumers have seen fit to challenge the material security of a range of products, they have hardly been in full control of events, but nor have they been passive victims of far-away decisions. Unfortunately, far too little is known about the ways in which patients, citizens, workers and consumers have negotiated their positions in relation to IHO policies, adding their agendas to those of other actors. If it is an under-researched topic then this collection has served the purpose of identifying an area for future work. 
Iris Borowy is Distinguished Professor in the College of Liberal Arts at Shanghai University. James H. Mills is Professor of Modern History at the University of Strathclyde. Ying-an Zhang is Professor of History in the College of Liberal Arts at Shanghai University. 


\section{References}

Amrith, Sunil, Decolonizing International Health. India and Southeast Asia, 1930-65. Basingstoke, 2006.

Bhattacharya, Sanjoy, The Global Eradication of Smallpox. Hyderabad, 2011.

Borowy, Iris. "International Social Medicine Between the Wars. Positioning a

Volatile Concept", Hygiea Internationalis, 6: 2 (2007), 13-35.

Borowy, Iris, Coming to Terms with World Health. Berlin, 2009.

Brown, Theodore, Marcos Cueto and Elizabeth Fee, "The World Health Organization and the Transition from 'International' to 'Global' Public Health", American Journal of Public Health, 96: 1 (2006), 62-72.

Carroll, Peter and Adrian Key, Global Health Governance and the OECD. World Scientific Publications, 2016.

Cueto, Marcos, ed., Missionaries of Science. The Rockefeller Foundation and Latin America. Bloomington, 1994.

Cueto, Marcos, The Value of Health. A History of the Pan American Health Organization. Washington, 2007.

Farley, John, To Cast Out Disease. A History of the International Health Division of the Rockefeller Foundation, 1913-1951. Oxford, 2004.

Fidler, David "The globalization of public health : the first 100 years of international health diplomacy", Bulletin of the World Health Organization, 79: 9 (2001), 84249.

Gillespie, James, "International organizations and the problem of child health, 19451960”, Dynamis, 23 (2008), 115-142.

Neville M. Goodman, International Health Organizations and Their Work. Edinburgh, 1952/1971.

Harrison, Mark, "Disease, diplomacy and international commerce: the origins of international sanitary regulation in the nineteenth century", Journal of Global History, 1: 2 (2006), 197-217.

Howard-Jones, Norma, International Public Health between the Two World Wars The Organizational Problems. Genf, 1978.

Howard-Jones, Norman, The Pan-American Health Organization: Origins and Evolution. Geneva, 1981.

Kelley, Lee, The World Health Organization. London, 2009.

Koivusalo, Meri and Eeva Ollila, Making a Healthy World. London, 1997.

Litsios, Socrates, "Fred L. Soper's Ignored Criticism of WHO's Approach to Malaria Eradication”, Parasitologia, 42 (2000), 167-172

Litsios, Socrates, "The Long and Difficult Road to Alma-Ata: A Personal Reflection", International Journal of Health Services, 32: 4 (2002), 709-732

Litsios, Socrates, "WHO, PHC and the NGO Community : the Need for a More Focused Commitment", Development Journal on Politics of Health, 47: 2 (2004), $57-634$ 
Litsios, Socrates, "The Christian Medical Commission and the Development of WHO's Primary Health Care Approach", American Journal of Public Health, 94: 11 (2004), 1884-1893.

Litsios, Socrates, "Selskar Gunn and China: The Rockefeller Foundation's 'Other' Approach to Public Health", Bulletin of the History of Medicine, 79: 2 (2005), 295-318.

Litsios, Socrates “The Rockefeller Foundation's Struggle to Correlate Its Existing Medical Program with Public Health Work in China” pp. 177-203 in Iris Borowy, ed., Uneasy Encounters: The Politics of Medicine and Health in China 1900-1937. Berlin, 2009.

Litsios, Socrates, The third ten years of the World Health Organization. Geneva, 2009. Litsios, Socrates, The fourth ten years of the World Health Organization. Geneva, 2012. Mendis, Kamini et al., "From Malaria Control to Eradication: The WHO Perspective", Tropical Medicine \& International Health, $14: 7$ (2009), 802-809.

Narayan, Ravi and Claudio Schuftan, "People's Health Movement," p. 124-127 in Guy Carrin et al., eds, Health Systems Policy, Finance and Organization. Oxford, 2009.

Palmer, Stephen, Launching Global Health. The Caribbean Odyssey of the Rockefeller Foundation. Ann Arbor, 2010.

Rodríguez-Ocana, Esteban, ed., The Politics of the Healthy Life. Sheffield, 2003.

Roemer, Milton, "Internationalism in Medicine and Public Health" pp. 1928-1939 in W. F. Bynum and Roy Porter, eds, Companion Encyclopedia of the History of Medicine. London, 1993.

Ruger, Jennifer, "The Changing Role of the World Bank in Global Health", American Journal of Public Health, 95: 1 (2005), 60-70

Staples, Amy, The Birth of Development. Kent, 2006.

Stapleton, Darwin, "Internationalism and nationalism: the Rockefeller Foundation, public health, and malaria in Italy, 1923-1951", Parassitologia, 42: 1-2 (2000), $127-34$.

Sridhar, Devi, The Battle Against Hunger: Choice, Circumstance and the World Bank. Oxford, 2008.

Ubalde, Ane and J.T. Jackson, "The World Bank and International Health Policy: A critical review", Journal of International Development, 7: 3 (1995), 525-541.

Weindling, Paul, ed., International Health Organisations and Movements 1918-1939. Cambridge, 1995.

Weindling, Paul, "As origens da participação da América Latina na Organização de Saúde da Liga das Nações, 1920 a 1940," Historia ciencia saúde-Manguinhos, 13: 3 (2006), 555-570.

Yan, Isabel, Eline Korenromp and Eran Bendavid, "Mortality changes after grants from the Global Fund to Fight AIDS, tuberculosis and malaria: an econometric analysis from 1995 to 2010", BMC Public Health, 15: 977 (2015). 